\title{
Chapter X
}

\author{
Sanctuaries on Mount Penanggungan: \\ Candi Kendalisodo, Candi Yudha, and the Panji statue \\ from Candi Selokelir - the climax
}

\section{GEOGRAPHICAL SITUATION AND LAYOUT OF THE SANCTUARIES}

Mount Penanggungan (1,653 m), situated approximately 50 kilometres to the south of Surabaya, has a peculiar shape (fig. 10.1). It has one central peak, which is surrounded by four lower summits and four more hills on a lower level, such that it resembles a natural mandala. ${ }^{1}$ The names of the four upper hills, starting from the one in the northeast and then proceeding clockwise, are Gajah Mungkur, Kemuncup, Sarahklopo, and Bekel (fig. 10.2). Most of the 81 sanctuaries or their remains are located on the northern and western slopes of the mountain. ${ }^{2}$

Many of the sanctuaries are grouped in such a way that their locations follow an ascending line on the mountain slope - for example, sites LXI, LXII, LXIV, LXVII, and LX on the western slope, starting from Candi Jolotundo (XXVII). Others are grouped together in close proximity - for instance, sites I, XVI, LIV, LII, LIII, LI, L, and IL on the upper western slope. Around Gajahmungkur ten sites are grouped close to each other: VII, XX, XXI, III, XIX, IX, XXII, XVIII, VIII, and LXIX. ${ }^{3}$ As not all the buildings are dated, we cannot conclude that these arrangements were the result of a plan. However, the addition of new sanctuaries may have allowed paths of procession and groups of sanctuaries to develop gradually. These sanctuary groups and lines may correspond with the so-called mandala which are mentioned in the Nagarakertagama

\footnotetext{
1 Compare my explanations on Mount Penanggungan in Chapter IV, sub-chapter 'Water and mountain'.

I use Romondt's (1951) numbering of the sites in Roman numbers.

I visited most of these sites during several climbs on the mountain since 1993.
} 


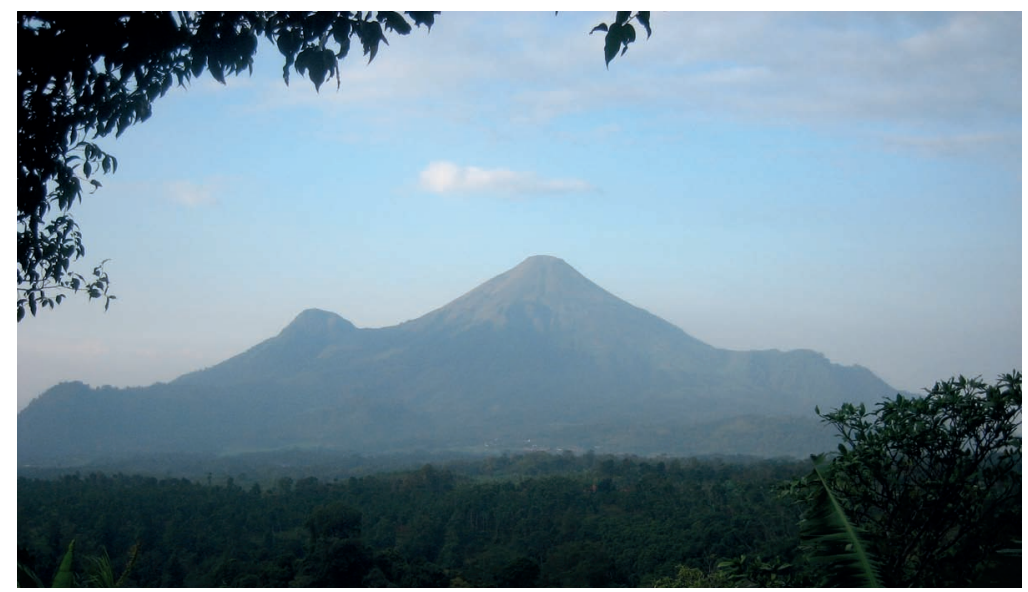

Fig. 10.1. Mount Penanggungan, seen from Trawas, from the south

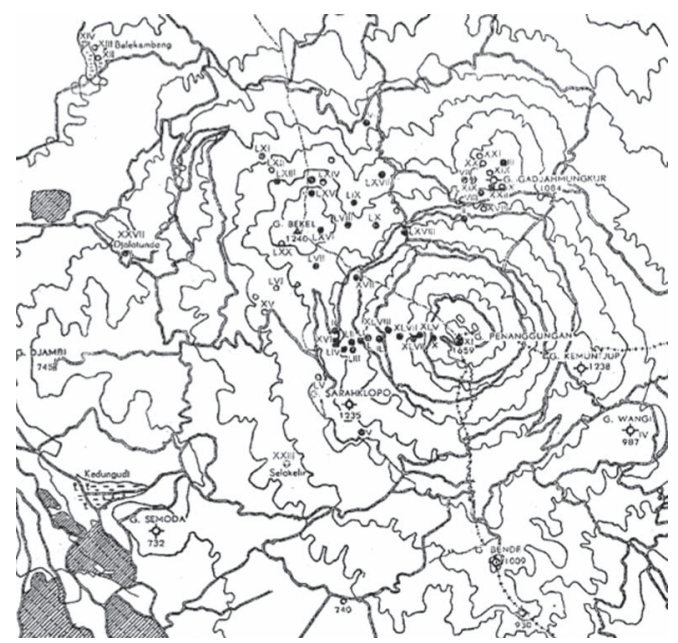

Plate 10.2. Topographic map of Mount Penanggungan

(Van Romondt 1951, Gb.A. Peta sementara letak ${ }^{2}$ kepurbakalaan di Gng Penanggungan) 
(Nag. 32.2c, 78.7a) and which Pigeaud (1960-63, IV:93, 247) translates as 'sacred-ring communities'. ${ }^{4}$

The majority of the sanctuaries on Mount Penanggungan are of a rather small scale. The building consists of several terraces - the typical feature in the religious architecture of the East Javanese period - with a central staircase. In many cases some of the terraces are decorated with narrative reliefs; however, at numerous sites the reliefs are no longer extant. Often one or three altars were found on the upper terrace of the sanctuary, perhaps originally with a statue placed on top of or near the altar. $^{5}$ In front of the terraced buildings were often small shrines to be used for offerings. It may be assumed that most of these elements - reliefs, altars, and shrines - originally existed at most of the sanctuaries. Some sites consist of several small, ascending courtyards with altars and terraced buildings. The terraces follow the incline of the slope and are oriented towards either the mountain peak or the peak of the hill on which they were built. I refer to them with the Indonesian term pemujaan (place of worship). ${ }^{6}$ The hermitages, pertapaan (place of meditation), consist of a natural rock-cave or are man-made constructions.

Sanctuaries with relief depictions of cap-figures are:

- Candi Gajah Mungkur (XXII) - dated AD 1360

- Candi Wayang (VIII) - probably approximately AD 1360

- Candi Yudha (LX) - probably mid fifteenth century

- Candi Kendalisodo (LXV) - probably mid fifteenth century

- Candi Selokelir (XXIII) sculpture - dated inscription from AD 1434

I have selected Candi Kendalisodo and Candi Yudha for detailed discussion because they represent two different kinds of sanctuaries (a hermitage and a place of worship) and also because their relief depictions display a different placement and arrangement. I investigate the sculpture from Candi Selokelir as one of only two known statues of cap-figures. The two other places are listed in the table in Chapter V, with brief information on their relief depictions.

\footnotetext{
4 Supomo (1977, I:66-8) and Hariani Santiko (1990:163-4, 1998:240-1) discuss various names that occur in Old Javanese literature and obviously all refer to hermitage communities: wanasrama, asrama, patapan, kadewaguruan, mandala, and karshyan.

$5 \quad$ As mentioned in chapter IV, Hariani Santiko (1998:245) argues that no sculptures were placed in the mountain sanctuaries. I, however, do not concur with this.

6 In Indonesian they are also called punden berundak.
} 
HISTORY AND FUNCTION OF THE SITES

Dates found in inscriptions on Mount Penanggungan range from the late tenth century until AD 1511 (Van Romondt 1951:52). The earliest dated site is Candi Jolotundo (AD 977), which is a holy bathing place located on the western foot of Mount Penanggungan. ${ }^{7}$ The majority of the buildings are located on the upper reaches of the mountain and date from the fifteenth century, with the bulk dating from around the middle of the century. This implies that most were built and used during the times of conflict in Majapahit, that is, between the Civil War in 1405-06 and the attack by Muslims from Demak in 1478. Reliefs with cap-figures only appear on buildings in the mountain's upper reaches and date from the middle of the fourteenth to the middle of the fifteenth century.

Mount Penanggungan is mentioned in several ancient Javanese texts and in oral traditions. There is evidence of a special connection with King Airlangga. The Calcutta-stone inscription, ${ }^{8}$ dated AD 1041, mentions that King Airlangga went into a retreat on Pucangan. The Nagarakertagama (Nag. 58.1, 78.1) mentions hermitages at 'Pawitra' and at 'Pucangan'. That Penanggungan/ Pawitra/ Pucangan are synonyms for each other has been argued by several authors. ${ }^{9}$ The term pawitra in Old Javanese, having its root in Sanskrit, means 'purifying; pure, free from evil, auspicious, sacred, holy' (Zoetmulder 1982:1329). This term refers to the sacredness which is ascribed to Mount Penanggungan due to its peculiar shape. The Old Javanese word pucang means 'areca-palm, areca-nut' (Zoetmulder 1982:1427), thus pucangan is the place of the areca palms. In fact 'wild areca palms were reported to have been growing on this mountain' (Rouffaer 1909:182). The name 'Penanggungan' is a name that developed more recently, which can be translated from Indonesian as 'enduring/suffering' or as 'being responsible'. ${ }^{10}$ The

\footnotetext{
7 Compare my discussion of this tirtha in Chapter IV, sub-chapter 'Water and mountain'.

8 So called because it was brought to the Indian Museum in Calcutta by Raffles in 1813. The inscription relates facts of King Airlangga's life. Kern (1917:85-114) translates both sides of the inscribed stone, one of which is in Sanskrit and the other in Old Javanese. These translations are also published in Kern 1885 and 1912.

$9 \quad$ Pigeaud 1924:215, 1960-63, IV:155, 239; Krom 1931:270; Noorduyn 1982:426.

1o I am, however, unsure about the meaning of these words in relation to the mountain.

I am grateful to John Miksic, who provides another interesting interpretation in his comments on my thesis (27-4-2009): 'I am inclined to think that the name derives from the sense of tanggung which means to carry on one's shoulders. This could be a reference to the four lesser peaks which appear to sit on the shoulders of the taller peak which symbolizes the head.'
} 
inscription on the Calcutta stone mentions that in AD 1041 the king founded a hermitage at Pugawat/ Pucangan (Rouffaer 1909:180-2; Krom 1931:259). ${ }^{11}$ According to traditional folklore, it is also believed that at the end of his life Airlangga himself withdrew from worldly affairs on Mount Penanggungan (Stutterheim 1937b:406-10; Supomo 1972:289-90). The traditional belief found in later semi-historical babad has it that Airlangga's daughter lived in the hermitage on Pucangan. In some of the Panji stories the aunt of Panji, Kili Suci, is a hermitess on Pucangan.

The Nagarakertagama (Nag. 58.1) relates that King Hayam Wuruk on his journey through the realm, coming from Candi Jawi, visited a hermitage on the slope of Mount Pawitra. This shows that the specific hermitage, or even the whole mountain, was so highly venerated by the king that he - probably accompanied by a large retinue - made the effort to climb the mountain, since hermitages are usually situated on a rather high level and are not easily accessible. Nag.78.1b mentions that Pucangan and Pawitra belong to the seven free domains of hermitages (dharma lepas karshyan) under royal authority; these hermitages received donations from the king so that poor rshi could fulfil their worshipping and ascetic practices.

The Tantu Panggelaran, which narrates the story about the move of Mount Meru from India to Java (Pigeaud 1924:62-6, 134-7), mentions 'Pawitra' as the mountain's top which fell down to the island of Java before the main part of the mountain was set down further to the east. Mount Penanggungan's peculiar shape, which corresponds to the description of the mythical Indian Mount Mahameru, and which is that of one central peak surrounded by eight summits, as well as its geographical location to the west of Mount Semeru, the highest mountain of Java, make it clear that the 'Pawitra' of the Tantu Panggelaran is Mount Penanggungan.

The Old Sundanese text Bujangga Manik from the late fifteenth or early sixteenth century, describing the journey of a hermit through Java, speaks of how the main character climbed Mount Pawitra and the sa-

11 The Sanskrit version of the inscription has the name 'Pugawat' while the Old Javanese one names it 'Pucangan'. Rouffaer (1909:180-2) and Kern (1917:113) explain that 'Mount Pugawat/Pucangan' are both synonyms for today's Mount Penanggungan. Very recently the identification of Pucangan with Penanggungan has been questioned, for example by Hadi Sidomulyo who suggests that the location of Pucangan is near the town of Jombang (personal communication on 24-09-2012). The issue requires further research. 
cred Mount Gajah Mungkur (Noorduyn 1982:258, 414). This highlights the importance of the mountain even during later times and for pilgrims from far away. All these historical and semi-historical sources reveal the existence of a long tradition of ascetic practice associated with Mount Penanggungan and its high esteem and status as a holy place.

The sites on Mount Penanggungan had different functions and served various purposes. Most of them were places of worship. It has been argued that these sites served for the worship of the ancestors and of gods, particularly and predominantly for the worship of Siwa (Hariani Santiko 1998:246). Others served as hermitages. Several sanctuaries combined both functions, as is evident from the layout of some sites, amongst them Candi Kendalisodo, and from the location of some sites in close proximity to each other. Further evidence is provided through the use of the terms karshyan/patapan/mandala as synonyms in ancient texts. For example, the Nagarakertagama (Nag. 58.1, 68.2, 78.1, 78.7) indicates these were groups of buildings which served as centres of religious education, as places to retreat from the world, and for worship of the ancestors and gods. ${ }^{12}$ Still other sanctuaries are holy water places, such as the two well-known and relatively early sites Candi Jolotundo (AD 977) and Candi Belahan (ascribed to the mid-eleventh century), and Candi Balekambang the remains of which bear some relief carvings.

The importance and meaning of Mount Penanggungan must be considered in the context of the cult of mountain and ancestor worship as a predominant feature in the religious practice in ancient Java. Mount Penanggungan in particular was considered as the holiest of the mountains, as the 'Lord of the Mountains' (Supomo 1972:290). On the slopes of other mountains in East Java, such as Mount Arjuno or Mount Lawu, hermitages and small sanctuaries were also built, but in far lesser numbers than on Mount Penanggungan. In a previous chapter I presented the long ongoing scholarly discussion about mountain and ancestor worship in East Java. ${ }^{13}$ The major issues are the resurgence of an ancient indigenous megalithic culture; the impact of the advance of Muslim power; and the chaotic and unstable political situation in fifteenth-century Majapahit, which led to an increased tendency to practise asceticism at remote sites. As mentioned before, the 'resurgence

12 Compare Agus A. Munandar (1990b:195-259); Hariani Santiko 1998. See also Chapter IV, subchapters 'Unity of the realm' and 'Decline of Majapahit'.

13 Chapter IV, sub-chapters 'Decline of Majapahit' and 'Water and mountain'. 
of a megalithic tradition' has been questioned in recent years, and I do indeed not consider this tradition to be a determining factor for the increase of mountain sanctuaries. The issue of an interconnection between the political instability and ascetic practice, however, is of particular importance and relevance for my object of research.

The principals, or donors, for the foundations of the sanctuaries were members of the wealthy or aristocratic society of Majapahit. This is suggested by the mention of 'Pucangan' and 'Pawitra' as free domains under royal authority in the Nagarakertagama (Nag. 78.1b). By commissioning architects and artists, these principals manifested their claim to be part of constituting the political order. Reality, with competitions in the aristocratic hierarchy during the time of political upheaval of the fifteenth century, was mirrored in fiction, with the struggle of Panji in the Panji stories. ${ }^{14}$ The frequent depictions of Panji stories in reliefs on Mount Penanggungan, and the Panji sculpture from the middle of the fifteenth century from Candi Selokelir, should be considered against this background.

The tradition of hermits living in remote areas had increased in the late Majapahit period, and their status had risen as well. Most likely, pilgrims from all parts of society, in particular members of the aristocracy and even kings, retreated to hermitages in seek of spiritual knowledge and power. The remoteness of the mountain from the world, from the noise and distractions of daily life, attracted pilgrims who sought the silence for inspiration and to reach an understanding of religious knowledge.

This remoteness corresponds to the secrecy of the esoteric Tantric knowledge, which lies beyond the basic religious and ritual practice. The more remote or higher up on the mountain, the deeper or higher you can progress towards attaining the secret Tantric knowledge. The beauty of the site, with its nature, forest, ravines, and spectacular views was regarded and perceived as full of awesome magic and spirits. This beauty contributed to the arousal of langö, which is a yantra for the unification with the Divine. The mountain thus became a yantra itself in achieving this union. After having reached, on the upper slopes of the mountain, the union with the Divine, in the understanding of the Tantric doctrine, the pilgrim would descend and take a bath in Jolotundo to unify with the

${ }^{14}$ See Chapter II, sub-chapter 'Panji stories'. Compare Hunter 2007. 
ishtadewata. This is the process of the Tantric Kundalini path: the ascent to the Sahasrara, followed by the descent to the Anandakanda-padma. ${ }^{15}$

The community of others searching for the same goal was certainly supportive of these religious seekers. The effort of climbing the mountain to reach the sanctuaries, however, means it is unlikely there were masses of people in this group, but rather that it was an exclusive community of worshippers and pilgrims. ${ }^{16}$

Water is a very important theme in the mythology of Mount Penanggungan and its sanctuaries. As elaborated in Chapter IV, water has a twofold symbolism depending on its function as amerta or tirtha. Following the Samudramanthana story in the version of the Tantu Panggelaran, Mount Penanggungan itself, as the top of Mount Meru, produces the amerta through the churning of the ocean. The tirtha, such as Candi Jolotundo, on the lower slopes of the mountain served for ritually purifying the pilgrims and, thus, for preparing them on their path to a higher stage of esoteric knowledge before they climbed the mountain. Earlier in this book I explained the symbolic identity of amerta and the semen of Siwa, which finds its manifestation in the lingga sculpture of Jolotundo, this sculpture mimicking Mount Penanggungan itself. Jolotundo comprises both meanings of tirtha and amerta: the water sources along the slopes of the mountain - manifestations of amerta - also have served for recurrent purification and preparation of the pilgrims in the sense of tirtha.

In a very practical way, water was necessary for the supply of the hermits and pilgrims with drinking water; during the rainy season, water was provided by brooks and water sources. We do not know how the situation was in the dry season, when water was scarce. There must have been people who provided the hermits and the pilgrims with food and water, and they certainly gained merit through these deeds.

Still today, some of the sanctuaries on Mount Penanggungan are visited by the local people, who bring offerings or meditate there. Candi Jolotundo is particularly respected; pilgrims come to take a ritual bath

15 See Chapter IV, sub-chapter 'Tantrism'.

16 I am grateful to John Miksic for his comment (27-4-2000) on the number of pilgrims visiting Penanggungan: 'This mountain is not particularly high. It is only about a thousand metres to the mountain's shoulder where the majority of the shrines are located. Jolotundo is located at 500 metres, from there it is only another 500 metres to the shoulder zone.' Furthermore, Majapahit's capital Trowulan, with its population of 'at least 100,000 at its peak', and located only about $30 \mathrm{~km}$ from Penanggungan, would have provided a large number of pilgrims. 


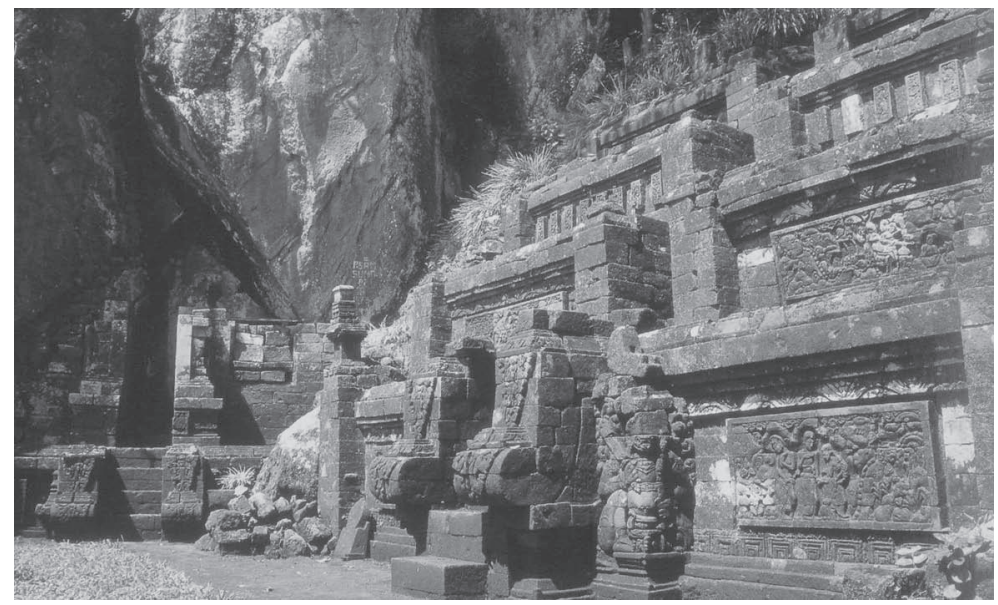

Fig. 10.3. Candi Kendalisodo, view from northwest (courtesy of Kinney 2003:260, fig. 262)

and to spend the night in meditation. On the other hand, in the course of time many sanctuaries or parts of them have been damaged or destroyed, and many reliefs stolen. During my visits to Mount Penanggungan since 1993, I was sad to find again and again that parts of the sites had been damaged or had disappeared, perhaps having found their way into the international art market so that they now in private hands.

\section{CANDI KENDALISODO}

This site - no. LXV - is located on the northern slope of Gunung Bekel, the northwestern hill below the peak of Mount Penanggungan, at a height of about 1100 metres. Access to the place requires a long, steep walk of three to four hours. The sanctuary consists of two parts, a terraced construction and a natural rock-cave which is closed by a manmade split gate (fig. 10.3). Both parts are decorated with narrative reliefs. All three reliefs on the gate walls have been stolen, and three of the four panels on the terraced structure have been damaged, but luckily photos 
of them have been preserved by the Dutch Archaeological Service. In addition, I was able to take some photographs in situ myself. ${ }^{17}$

Candi Kendalisodo served both as a pemujaan and as a pertapaan. There are no inscriptions or dates. Stutterheim (1940:132) dates the site to the middle of the fifteenth century, as most of the sanctuaries on the upper level of Mount Penanggungan are from that time. I agree with this date, as this dating is supported by the style of the reliefs. In the following discussion of the site, I will refer to my earlier article (Kieven 2000); however, at some points in this chapter I will suggest new interpretations, which I have developed since then.

Candi Kendalisodo has the highest position in a group of five sites (LXI-LXV). The other four sites are scarcely visible. Inscriptions were found at site LXI, dated AD 1414, and at site LXIII, dated AD 1404. An inscription from site LXIV was read as AD 1410 or 1451. Site LXIII was a simple hermitage, and at LXIV the image of a dwarapala was found (Van Romondt 1951:36-7). These sites probably formed a mandala group of both pemujaan and pertapaan. Due to the fact that it occupies the geographically highest position and is the largest in size within this mandala, Candi Kendalisodo may have been the central and most important place in this mandala. ${ }^{18}$ Visitors enter the small plateau, which opens to a spectacular view over the northern plains of the Brantas delta. The pemujaan is situated at the south side of the plateau, and the pertapaan at the east side.

The pemujaan consists of three terraces with a central staircase. The two lower terraces are decorated with four large relief panels which must be read starting on the first terrace from left to right (panels 1 and 2); on the second terrace from right to left (panels 3 and 4). ${ }^{19}$ They feature a noble couple, the male wearing a cap as headgear. Due to weathering the carving of the cap is less clear in some panels, while a sharp-edged cap is visible only in panel 3. The lady, her long hair loose, has the typical features of a young noblewoman. Another couple is comprised of a

17 The relief depicting Bhima and the one depicting the temptation scene of Arjuna were stolen around 1992; the relief depicting the bathing widadari was stolen around 1997 (information by Pak Paedan, the juru kunci of Kendalisodo and of other Penanggungan sanctuaries, on 16-6-2010).

18 As mentioned in Chapter IV in my discussion of mountain sanctuaries, Supomo (1977:67-8), Agus A. Munandar (1990b:202-3), and Hariani Santiko (1988:240-1) point to the existence of such hierarchies within a kadewaguruan/mandala.

19 Two of the panels have been damaged since 1996; very sadly, the upper parts of the body, including the cap of Panji, have been cut out. Luckily I took photos of the complete panels in 1996. 
maid servant with the typical hair bun, and a small, dwarf-like panakawan. Obviously the maid servant is the companion of the noblewoman and the panakawan the companion of the nobleman. The cap-figure has been interpreted as Panji (Holt 1967:89; Terwen-de Loos 1971; Kieven 2000).

In my earlier article (Kieven 2000), I identify the narrative with the Jayakusuma story. This story was very popular in the nineteenth century in Surakarta; however, no earlier written versions are known. ${ }^{20}$ It speaks of Panji and his betrothed Candrakirana who, before getting married, are ordered by his parents to visit his grandparents who live on the island of Borneo and pay homage to them. While they are crossing the ocean by boat, a storm separates them and brings him to Borneo and her to Bali. Only later, after many adventures, do they meet again. ${ }^{21}$ I am less certain now that I interpreted this narrative correctly. However, the topics of crossing of the ocean and the subsequent separation of the two protagonists, both of these topics constituting crucial elements in the Jayakusuma story, are also to be found in several other Panji stories. Thus, maybe another unknown version served as the source material for the depiction at Kendalisodo. ${ }^{22}$

The first panel (fig. 10.4) depicts the two couples within a compound consisting of several buildings and enclosed by a wall, which suggests an aristocratic ambience. In the main building two people are pictured sleeping. The two aforementioned couples kneel while making the gesture of sembah towards the sleeping persons, which means they are taking leave. Obviously this happens in the night or the early morning, a time when Javanese people still today set out on a journey to avoid the heat of the day. The second panel (fig. 10.5) shows the same two couples walking in a beautiful landscape marked by rocks, trees, and a flagstone path winding through the mountains. The panakawan carries a vina, a stringed

\footnotetext{
${ }^{20}$ Poerbatjaraka (1940a:103) discusses the story, same as Padmapuspita (n.y.). A summary of the plot is also provided in Sulastrin Sutrisno et al. 1983:37. Coster-Wijsman (1952) discusses a textile with depictions of the story in wayang style, kept in the Royal Tropical Institute in Amsterdam.

${ }^{21}$ Terwen-de Loos (1971) gives another interpretation of the reliefs, which is based on the life story of Raden Wijaya, the founder of Majapahit, as told in the Kidung Harsa Wijaya. On many points this interpretation is not at all convincing to me. According to Terwen-de Loos, the episode in the reliefs depicts the part of the story after Raden Wijaya has fought against the Kediri attack, this fight forming an important part of the story. If it were so, then in my opinion some reference to the fight would be illustrated in the reliefs. Beyond this, Terwen-de Loos mixes up the relief panels. Thus, I cannot follow her interpretation.

22 Another interesting point related to my interpretation is Soekmono's (1995:102) note, referring to Van Hoëvell (1851, II:111), that in 'popular lore, Jolotundo was a tomb prepared for the Jenggala king Panji Joyokusumo'.
} 


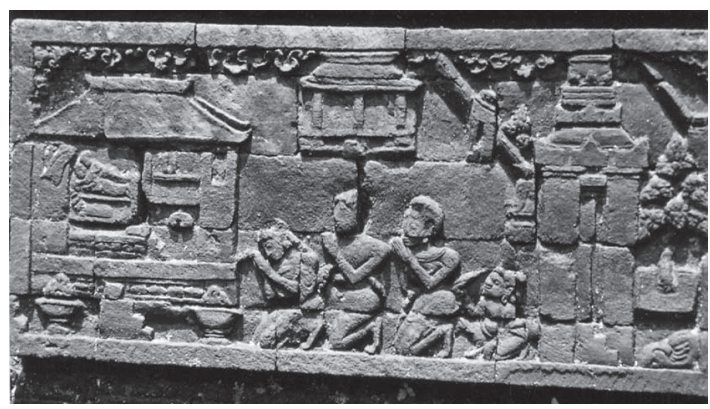

Fig. 10.4. Candi Kendalisodo, pemujaan, first terrace, left of staircase, panel 1

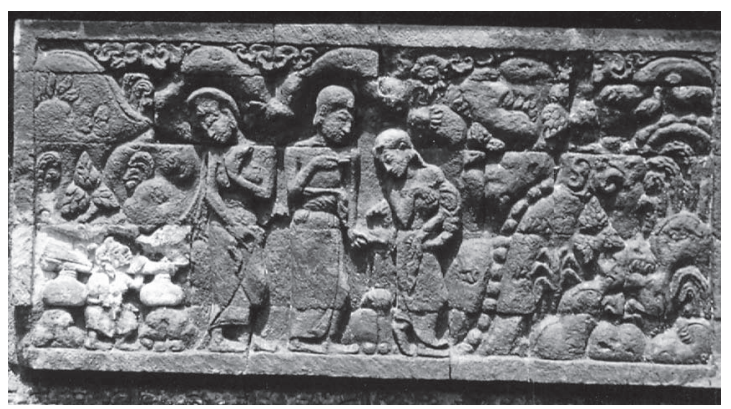

Fig. 10.5. Candi Kendalisodo, pemujaan, first terrace, right of staircase, panel 2

instrument with two gourd resonators connected by a shaft, which is known in India. ${ }^{23}$

The third panel (figs. 10.6a and 10.6b), on the upper right side on the second terrace, depicts the nobleman holding the young woman on his lap and playing the vina. ${ }^{24}$ They both have the postures of a loving couple

${ }^{23}$ The fact that the vina is depicted is remarkable. It is the only known depiction of this instrument in ancient Javanese art, especially in this relatively late phase of Indian influence in Java. It perhaps reflects an increased contact with Indian traders at that time. Kunst (1968:20) explains this instrument has similarities with the North-Indian bin and the South-Indian vina. I was lucky to be given the opportunity by Ernst Heins, ethnomusicologist in Amsterdam, to examine the original correspondence between Jaap Kunst and Willem Stutterheim in 1936 on this subject. A translation of a few passages from the Dutch says: Stutterheim (10-1-1936): '[...] one of the newly found reliefs of the Penanggungan on which a beautiful and clear rendering of a zither with two gourds. [...] Nice find, isn't it?' 'Kunst (12-2-1936): 'I would be delighted to receive a photograph of the Penanggugnan-vina or rather bin, for it is the typical North Indian shape of this string instrument. [...] In the reliefs of the Bayon such double gourd bins are also shown.' [I am grateful for the translation by J. Fontein.]

${ }_{24}$ The upper part of the male's body has been destroyed. 


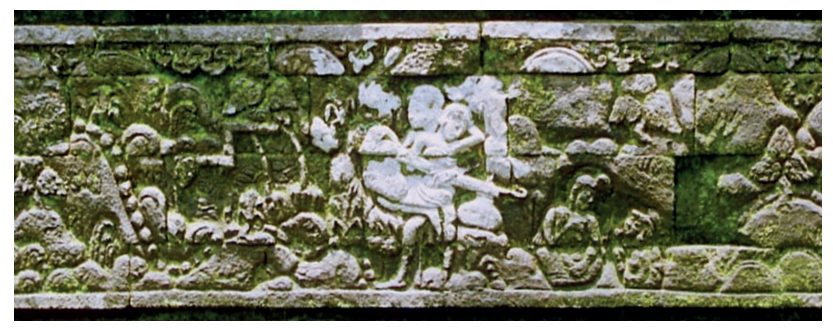

Fig. 10.6a. Candi Kendalisodo, pemujaan: second terrace, right of staircase, panel 3 (photo 1996)

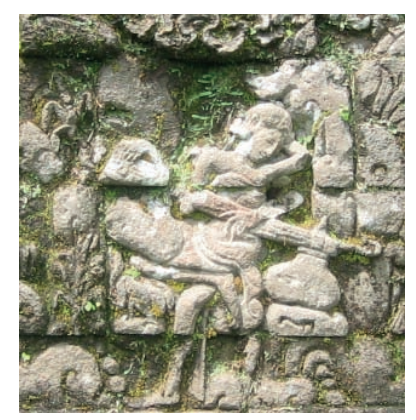

Fig. 10.6b. Detail of panel 3 (photo 2010)

in union. The romantic atmosphere of this situation is intensified by the depiction of a lake with waterspouts where they have taken a break on their journey. The servant couple is depicted below to the right, sitting and chatting to each other.

The fourth and final panel (figs. 10.7a and 10.7b) depicts on the right the same landscape as in the two previous panels - rocks, trees, and the flagstone path - and on the left, waves, sailing boats, and huge fish, indicating the ocean. On the ocean shore kneel the servant couple; to their right stand the noble couple, the male looking back to the lady and pointing with his right hand towards the ocean. ${ }^{25} \mathrm{He}$ seems to be explaining something to her concerning the ocean.

25 The upper part of the male's body has been destroyed. In both cases, in panel 3 and 4 , today visitors will not easily or not at all understand the depictions, since the interaction between the nobleman and the lady remains unclear without the lost parts. 


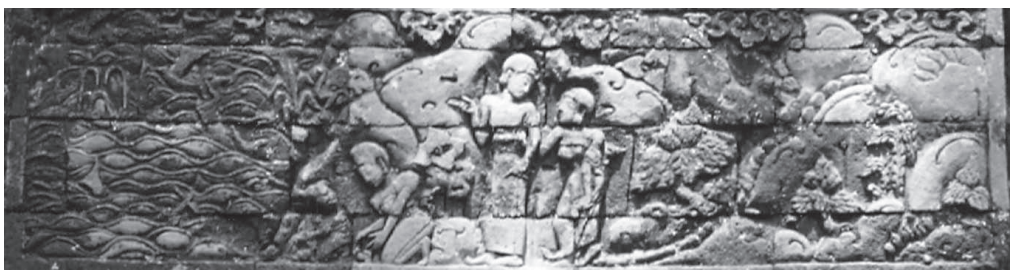

Fig. 10.7a. Candi Kendalisodo, pemujaan, second terrace, left of staircase, panel 4 (photo 1996)

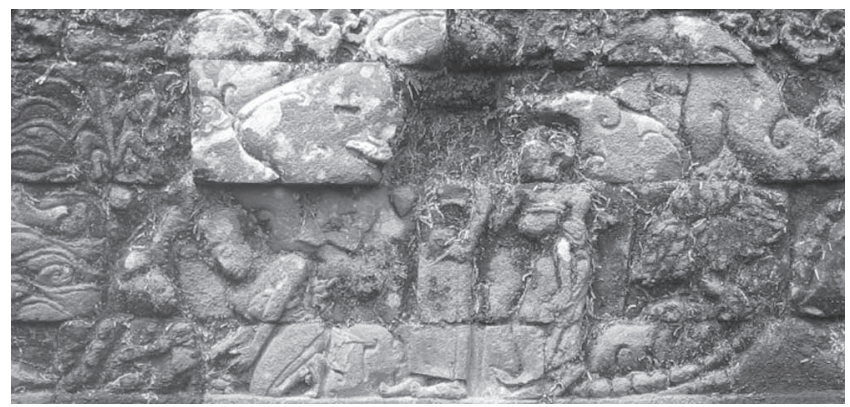

Fig. 10.7b. Candi Kendalisodo, pemujaan, detail of panel 4 (photo 2010)

Many elements in these depictions are typical for Panji stories: the prince and princess in an amorous situation, accompanied by their servants on a journey; Panji displaying his poetical and musical talents; situations with water. A separation is not explicitly shown, but if indeed the Fayakusuma or a story with a similar plot is depicted then the scene in the last panel and Panji's gesture towards the sea indirectly suggests the upcoming separation: when crossing the ocean the two lovers will be separated, while the original purpose is to pay homage to his grandparents on another island across the ocean. However, perhaps it is merely the theme of crossing the water which is given priority without any reference to what might actually happen.

The fact that the major elements of Panji stories are extant, and that the nobleman wears the cap, allows us to conclude that the depiction of a Panji story was in fact intended. Furthermore it has to be considered that the reliefs at Candi Kendalisodo, due to its rather late date of construction within the Majapahit period, stood in a long tradition of depictions 
of Panji stories, so that the presentation of but a few selected features was sufficient enough for visitors to identify these reliefs as a Panji story.

As discussed earlier (Kieven 2000), the whole sequence may symbolically suggest the journey which visitors to this sanctuary had undertaken themselves. They also had left their family, probably in the night or very early morning; they had walked through a beautiful landscape with rocks, ravines, and woods, following a steep path on the mountain slope; they certainly took a rest, if possible at a water site at the lower slope of the mountain. They did all this in order to pay homage to the ancestors, which is one of the purposes of visiting this sacred site on the mountain. The second purpose is to seek advice and listen to the teaching of a hermit, suggested by Panji's hand indicating the direction towards the pertapaan.

I want to call particular attention to the motif of water in both the third and fourth panel. The depiction of the lake with waterspouts in the third panel recalls the holy water places Candi Jolotundo (on the west side), Candi Belahan (on the east side), and Candi Balekambang (on the north side) on the lower levels of Mount Penanggungan. There most likely existed other tirtha places in former times. Thus, from wherever the pilgrims began their ascent to Candi Kendalisodo, they would certainly pass by a water place. This is taken up in the relief depiction, thus supporting my impression that the visitors are directly addressed in the illustrations so they can identify themselves with the depicted persons. The relief thus visualizes the symbolic meaning of the Bathing Places on Mount Penanggungan: purification and preparing for the passage to Higher Knowledge. The depiction of the ocean in the fourth panel indicates the crossing of water in order to proceed to the spiritual teaching which is then conducted in the hermitage.

In a certain way, the theme of the final episode of the Panji story is carried on in the relief depictions on the pertapaan. The three panels depict two scenes from the Arjunawiwaha and one from the Bhimasuci story. ${ }^{26}$ Two panels feature scenes in which water is predominant. To the left of the gate a panel depicted the widadari bathing in water, and to the right of the gate there was the popular scene in which two widadari try

${ }_{26}$ None of these three original panels is still extant today, the panel with the bathing widadari only having been stolen in recent years. 


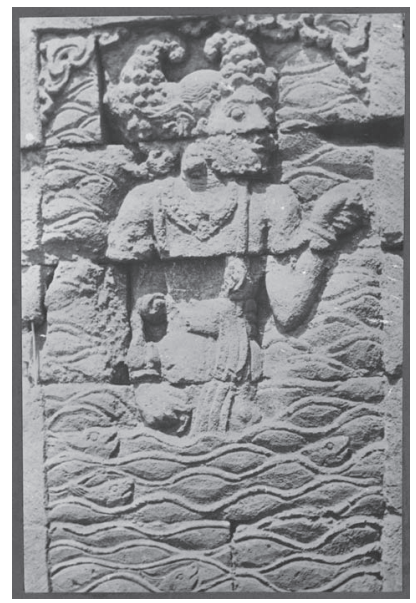

Fig. 10.8. Candi Kendalisodo, pertapaan, Bhima relief (courtesy of Kern Institute, Leiden University, OD nr. 12634)

to seduce the meditating Arjuna. ${ }^{27}$ The upper left panel depicted Bhima entering the ocean, the crucial moment in the Bhimasuci story before he meets Dewaruci on the bottom of the ocean (fig. 10.8); there he is taught how to find the Supreme Knowledge and the amerta. ${ }^{28}$ Bhima's headgear is a supit urang.

My interpretation of the site runs as follows: Candi Kendalisodo as a whole is a mirror of the gradual approach of the worshipper to the final encounter with the Divine. In this scenario, the Panji story and particularly Panji with Candrakirana function as companions and guides for the pilgrim, owing to the popularity of this story and its connection to daily life. In the pemujaan the worshippers first pay homage to the ancestors and proceed symbolically towards the mountain top. Along the way the depicted union of Panji and Candrakirana - in the romantic scene symbolizing the sexual intercourse - is another part of the preparation of the adept, suggesting the final union with the Divine according to the Tantric concept. The adept is then, with the depiction of the last panel, directed to go down to the water, which he/she finds back at the hermit-

${ }_{27}$ Other examples can be found at Candi Surowono, Candi Kedaton, and in a single stone from Kediri (compare Kieven 1994).

${ }_{28}$ See Chapter IV, sub-chapter 'Water and mountain'. 
age. There he/she can seek teaching from a living hermit. The reliefs on the hermitage walls demonstrate for the adept what he/she is supposed to do: first to clean him/herself, as depicted in the scene of the widadari bathing in the lake which symbolizes purification through passing tirtha. In a second step the adept would meditate and control the senses as does Arjuna. In a third step he/she would enter the water, as does Bhima. In this final step he/she will proceed to the Highest Knowledge - by the spiritual passage through tirtha, and eventually followed by achieving amerta. The hermit will give the appropriate advice in this process.

What I have just explained corresponds to the Tantric Kundalini path. Kendalisodo represents a quasi-concise form of this path, which we find in a more extended way in Candi Panataran. The adept follows the movement of the Kundalini in the body upwards to the Sahasrara-cakra, which accords the ascent to the top of the pemujaan. Then the adept goes down to the Anandakanda-padma, symbolized in the pertapaan in two depictions of water: the widadari scene and the final scene of Bhima entering the ocean. The temptation scene of the Arjunawiwaha, showing both erotic and ascetic qualities, displays the quintessence of this process. ${ }^{29}$

We have seen that the illustration of water at Candi Kendalisodo is a predominant feature: in two panels of the Panji story on the pemujaan, and in two panels on the pertapaan water plays a dominant role. As mentioned, the depictions of water here symbolize both amerta and tirtha in the respective panels. Furthermore, at this specific place on the slope of Mount Penanggungan water is an important topic per se, since it is a symbol of the amerta which emerges from Mount Meru.

Another form of symbolism on the political level is the struggle of young royals within the political hierarchy. As mentioned before, the increasing number of sanctuaries on Mount Penanggungan during the fifteenth century may reflect the political instability of this late phase of Majapahit, when many members of the aristocracy sought advice of hermits or even withdrew from daily life to remote areas on mountains. The story of Prince Panji, who struggles to become an accomplished kshatriya, was a model for these royals. In identifying with him, they were here at Candi Kendalisodo introduced to the encounter with the hermit in the pertapaan. The frequent depictions of Panji in other sanctuaries on Mount Penanggungan confirm the important role attributed to Panji. 
In comparing the pemujaan with the pertapaan we find the typical dichotomy in the layout of a temple: that between the mundane world and the sacred world, respectively. This dichotomy is expressed in the style and the way the male protagonists of the stories are depicted. The Panji story has the typical features of the 'post-mythological stories', while Arjuna and Bhima belong to the 'mythological stories' which are based on the Indian epics. As in other sites, the Panji story prepares and introduces the visitor to the sacred sphere. Panji acts again as an intermediary.

Candi Kendalisodo maintained the highest place in the spiritual hierarchy within a mandala group. It makes sense that this highest place was decorated with reliefs illustrating the approach to the highest level of esoteric knowledge. The high aesthetic quality of the reliefs, with the beautiful images on the stone walls, and the beautiful scenery of the place itself formed part of this approach. The aesthetic attraction of hermitages was a common feature in Old Javanese poetry (Supomo 1977:68). The Nagarakertagama (Nag. 32) reports on the forest hermitage of Sagara, which was visited by the king. The poet describes the beautiful scenery in detail, as well as the stone carvings on the walls. Langö is the means to achieve the goal of the final union with the deity and the liberation 'from the snares in which the world keeps man trapped' (Zoetmulder 1974:185). This can easily be transferred to the situation of the retreating seekers of truth on the mountain sanctuaries, remote from the world, who would experience langö by watching the reliefs and enjoying the beautiful scenery. ${ }^{30}$

\section{CANDI YUDHA}

Candi Yudha - no. LX - is located on the northwestern saddle between the Bekel Hill and the body of Mount Penanggungan at a height of about 1,000 metres. This sanctuary is of the pemujaan type, with four terraces and a central staircase. It is dated to the year AD 1486. During the time of Van Romondt (1951) the relief decorations were still in situ, and there was a small shrine in front of the temple. When I visited the place in 1996, all reliefs and the shrine had gone. However, photos by the OD

\footnotetext{
3o Patt (1982) has elaborated on the natural beauty of the scenery of many sites. She reasons that the choice of such places to erect a sanctuary was in fact deliberate.
} 


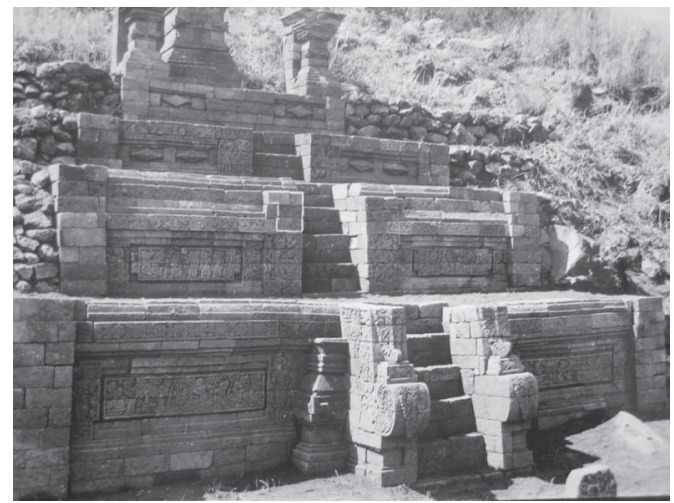

Fig. 10.9. Candi Yudha

(courtesy of Kern Institute, Leiden University, OD nr. 12052)

from the early twentieth century provide us with excellent images of the site and the reliefs.

Candi Yudha (fig. 10.9) is part of a group of three sanctuaries, the others being the sites LXVI (Candi Naga II) and LXVII (Candi Pandawa); all three are terraced sanctuaries. ${ }^{31}$ There are several ways to access Candi Yudha, but one would always start at Candi Jolotundo and follow a long line of sanctuaries on the western slope of the mountain to a certain point beyond Candi Sinta (no. XVII), where you would turn onto a sidetrack leading to the three sites. All three places offer beautiful views of the mountain peak and, through the saddle between the hills of Bekel and Gajah Mungkur, towards the plain of the Brantas River and the ocean, which is visible on clear days.

The temple is decorated with four long relief panels on the two lower terraces. ${ }^{32}$ One reads the reliefs, starting on the first terrace, from the right to the left panel, and on the second terrace, from the left to the right panel.

The two lower long panels depict scenes from the Arjunawizwaha (figs. 10.10 and 10.11). The right panel has the scene where God Indra sends out the heavenly nymphs to seduce Arjuna. One of the widadari has

${ }^{1}$ Candi Pandawa, AD 1511, is the most recent of all Penanggungan sanctuaries. The relief panels at this site, today no longer extant, illustrated scenes, presumably from the Mahabharata (Van Romondt 1951:41-3).

32 In my descriptions I will use the present tense, although the place is very much damaged today. 


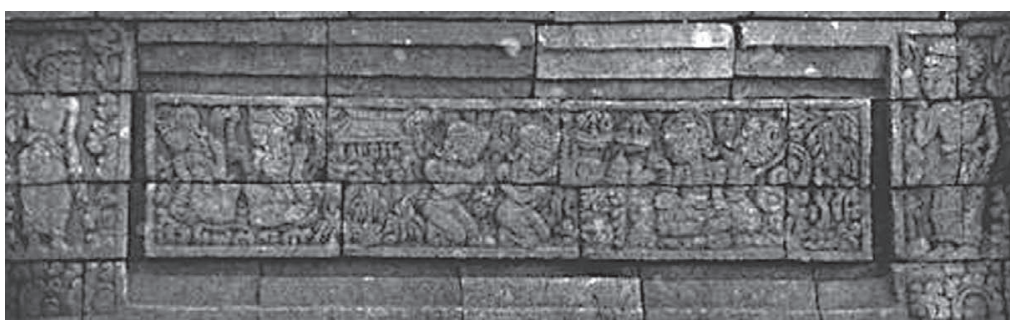

Fig. 10.10. Candi Yudha, first terrace, right side of the staircase (courtesy of Kern Institute, Leiden University, OD nr. 12055, cropped from the original)

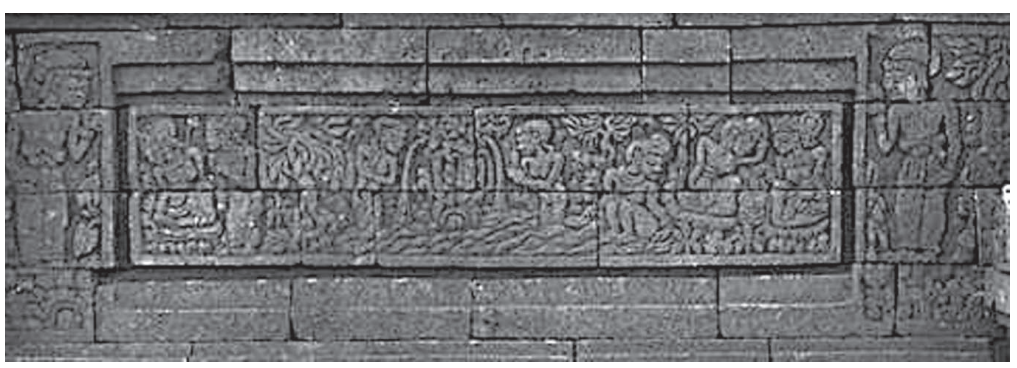

Fig. 10.11. Candi Yudha, first terrace, left side of the staircase (courtesy of Kern Institute, Leiden University, OD nr. 12057, cropped from the original)

adopted an erotic posture, anticipating the encounter with Arjuna. The left lower panel depicts the scene of the seven widadari preparing for Arjuna's seduction, six of whom bathe while Suprabha watches them. The six bathing nymphs are all in erotic postures. Both are important scenes in the Arjunawiwaha story. They display similarities, concerning the depiction's composition and iconography, to the corresponding scenes depicted in Candi Surowono. ${ }^{33}$ In both scenes Suprabha, who plays a principal role in the story as the most beloved by Arjuna, is depicted with a crown; this distinguishes her from the other nymphs, who have a simple hairdress. The second panel displays the six nymphs next to Suprabha in very erotic positions. 
The two long panels on the second terrace illustrate scenes from the Ramayana. On the left side of the staircase Rama teaches Wibhisana, the brother of the demon king, the asta brata, the eight rules for a righteous king. They are accompanied by Lakshmana, the monkey king Sugriwa, his general Hanuman, and Anggada. On the right panel the demon king, Rahwana, orders the waking up of his other brother, Kumbhakarna. On either side next to the staircase, the left pillar portrays Sugriwa with Hanuman standing behind him, while the right pillar depicts Kumbhakarna who faces the threat of the two monkeys. The third terrace has no long relief panels, but the pillars next to the staircase are again decorated with figures of the Ramayana story: on the left-hand side, Sugriwa with Hanuman, the latter on his way to fly across the ocean to Lengka (fig. 10.12); on the right-hand side, Rahwana, who faces the monkeys. ${ }^{34}$ Thus in the depictions on the two upper terraces there is a division between the left side featuring Rama with his followers and the right side featuring the demons.

Each of the two panels on the first terrace are framed to the right and left by a standing figure in noble attire. These figures face the respective panel and hold one arm up. On the right side of the staircase they both point to the left, which is to say the outer figure indicates towards the panel, and the left figure indicates towards the staircase and at the same time towards the following panel. The two figures framing the second panel both point to the panel itself. In both cases the figures seem to invite the viewer to take a look at the episodes in the panels. The figures at the inner sides next to the staircase have a sharp-edged crescent-moon shaped cap, while the headgear of the outer figures is a kind of wig with curls of hair shaped in the form of a cap. Such a headgear is known from the depiction in the Gambyok relief (c. AD 1400) where this wig figure acts as a companion of Panji; he is a specific kind of kadeyan, an arya or rangga of the same noble status as Panji. ${ }^{35}$ This character seems to have become popular during the late Majapahit period.

I interpret these reliefs as follows: the figure with the sharp-edged cap is Panji or else symbolizes a young royal person who has the same status as Panji. He and his companion welcome the visitors and present themselves as introducers and intermediaries between the mundane world

34 The Ramayana reliefs have been described and interpreted by Stutterheim (1938:29), but he does not describe the relief panels of the lower terrace. See also Van Romondt 1951:35.

35 See Chapter III, sub-chapter 'Kadeyan'. 


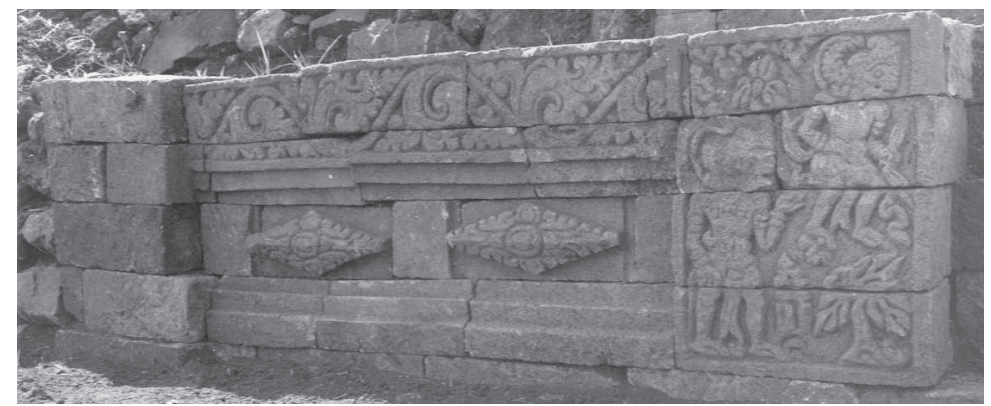

Fig. 10.12. Candi Yudha, panel on the third terrace, depicting Sugriwa and Hanuman.

(courtesy of Kern Institute, Leiden University, OD nr. 12061)

from which the worshippers come and the sacred world which they are entering. The first step into the sacred world is illustrated by the dispatch of the widadari by God Indra, and by their preparation and purification in water as depicted on the lower level. Panji and his companion point to this preparation. Both scenes are highly erotic and suggest, in an indirect way, the union of male and female, the goal of the Tantric path. Although not illustrated here, it is known from the Arjunawiwaha story that Arjuna could only consummate his marriage with the widadari after some struggles: several trials during his meditation, including the temptation by the widadari, and, finally, the successful fight against the demon Niwatakawaca. ${ }^{36}$

The upper levels contain scenes from the Ramayana presenting the preparation for the fight between Rama's army, under the leadership of Hanuman, and the demons. The ambiguity between loyalty to Rahwana and resistance against him is thematized in the two differing characters of Rahwana's brothers, Wibhisana and Kumbhakarna. The ideal kingship is then symbolized as the solution to this ambiguity in Rama's teaching of the asta brata towards Wibhisana. The emphasis placed on Hanuman, who is featured in three scenes, refers to his particular role in the late Majapahit time, when his mystical qualities were highlighted

${ }^{6}$ Compare the discussion in Chapter VIII (Candi Surowono) on the Tantric character of the Arjunawiwaha. 
and he was upgraded to the status of a semi-deity. 37 The upper terraces of the temple present a parallel to the task that is waiting for Arjuna to be fulfilled: his fight against the demon Niwatakawaca. Thus the Ramayana scenes are a continuation of the Arjunawiwaha scenes. After the successful fight - Rama and Hanuman against Rahwana, or Arjuna against Niwatakawaca - the hero can proceed to be fully recognized as a kshatriya, thus meeting all conditions to become a king. The selection of the specific scenes places the focus on the aspects of eroticism, preparation for the practice of asceticism, and ideal kingship. The actions of Arjuna and Rama are also preparations to eventually become reunited with Suprabha and Sita, respectively.

This mythological process parallels the preparation of a young royal to ascend in the hierarchy: by being introduced to the Tantric doctrine, by being confronted with the fight against opponents, and by being taught the ideals of a righteous king, he would finally fulfil the preconditions to become an accomplished kshatriya.

On the esoteric level, through the erotic situations on the lower level of the sanctuary, the visitor is attuned to the Tantric path, and he/she must go along this path via many struggles in order to reach the union with the Divine. As the Tantric teaching was highly secret, it makes sense that only the preparations to the Tantric goal were depicted in the reliefs and that the final goal, the union of Siwa with Sakti - which in the two stories is symbolized in the union of Arjuna with the widadari or by Rama with Sita - was left to the mere imagination of the worshipper. It is highly probable that there was a spiritual teacher who provided the complete explanations so the adherent would understand. We may imagine that the final teaching was sought for in a hermitage in the vicinity of, or further up on, the mountain.

It is remarkable that here in Candi Yudha both terraces have depictions of a kakawin based on the Indian Mahabharata, as usually kakawin are only displayed in the upper terraces of a temple. The Panji and kadeyan figures only appear on the lowest terrace, which accords to their usual placement within a temple. The fact that they are depicted outside of the actual narrative illustrations, and that they are taller than the protagonists in the panels, allows them to appear on the same level as the worshippers. This is comparable to the depictions of standing figures in the

37 In the final panel on the upper terrace, he is ready to fly to Lengka to encounter Rahwana, who is facing him. Compare Kieven 2011, and Chapter VII on Candi Panataran. 
Inner Bathing Place at Candi Panataran and at the entrance of Candi Mirigambar. They are themselves not involved in any narrative, but, rather, only act as companions and guides. In this way their function as introducers/intermediaries to the sacred world becomes clear. The four figures in Candi Yudha point with their hands to the respective panel or to the following panel. Panji himself is depicted next to the staircase, such that he is closer to the next step to the upper terraces symbolizing the more sacred sphere, while the kadeyan figure occupies the outside position with a stronger connection to the mundane sphere. The water in the bathing scene of the widadari has the purifying function of tirtha, just as it does in the scene on the hermitage wall of Candi Kendalisodo. Thus the pilgrim is purified and prepared for the encounter with the sacred sphere before going further in this visit of the pemujaan. The placement of the four figures on the corners has the same function as those at Candi Panataran, Candi Surowono, and Candi Mirigambar, where the scenes on the corners function to introduce the pilgrims to the temple's important message. The corners thus have the same function as elsewhere the lower or entrance part of a temple has.

None of the three sanctuaries - Naga II, Pandawa, Yudha - forming one mandala group, shows signs of having a hermitage. They are all terraced sanctuaries (pemujaan) for worship, with no recognizable hierarchy in their respective location or in architecture or decoration. We can imagine that the pilgrims on their way to hermitages on the mountain visited these pemujaan; these visits served as a preparation for their encounter with the religious teaching in the hermitages. The Yudha reliefs constitute a visualization and thus a symbol of this preparation. ${ }^{38}$

\section{THE PANJI STATUE FROM CANDI SELOKELIR}

This statue (fig. 10.13a) is one of the only two known three-dimensional images depicting a nobleman with a cap. The Selokelir sculpture from the middle of the fifteenth century represents the climax in the development of the Panji cult in the Majapahit period. A few features typical of the depiction of a deity characterize this Panji figure as an object of worship in a way similar to the worship of a deity, however, without 


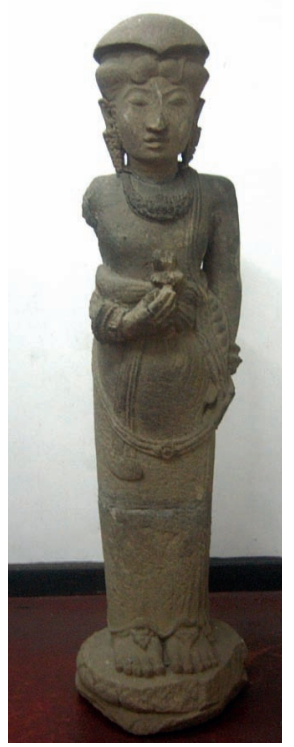

Fig. 10.13a. Panji sculpture from Candi Selokelir
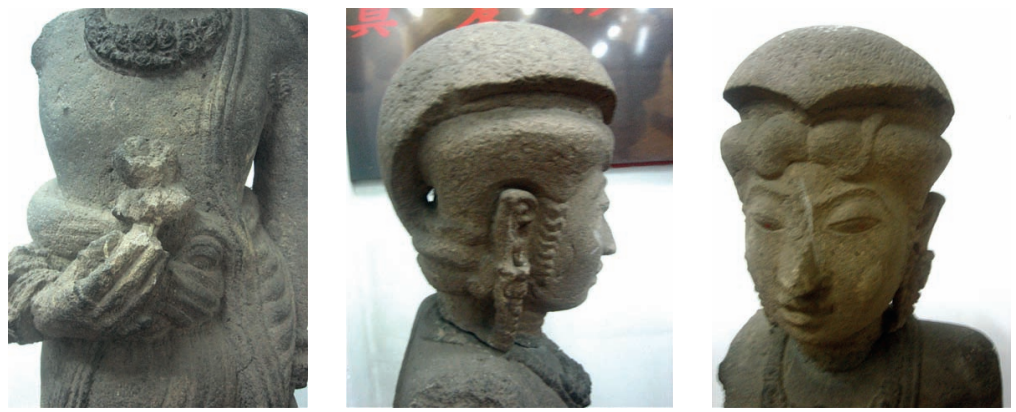

Fig. 10.13b-d. Details of the Panji sculpture from Candi Selokelir

being regarded as a deity himself. This is comparable to the ascent of other heroes, such as Bhima and Hanuman, to a semi-divine status in the same time period. Based on the well-established role of Panji as an intermediary, this Panji image incorporated the same function of introducing pilgrims to the sacred world and to esoteric teaching. Displaying both human and divine features, Panji had developed to be the ideal character to act as this intermediary. 
The ruins of Candi Selokelir are located on the southwestern slope of the hill Sarahklopo, which is the southwestern of the eight hills surrounding the peak of Mount Penanggungan. In 1900 the site was visited, and later documented, by the Dutch official Broekveldt (1904). The local people in those times called the site Watoe Kelir. ${ }^{39}$ Broekveldt mentions the ruins of two terraced sanctuaries and of another building. He describes the place as having an extraordinarily beautiful view. This gave Rouffaer (1909:182) the idea that this site was perhaps identical with the hermitage of Panji's legendary aunt Kili Suci. Krom (O.V. 1915:2) describes six monuments which originally stood on the plateau of this site. After a recent meticulous restoration, undertaken by the Archaeological Service, the typical terraced structure of a pemujaan, having one central staircase, is now clearly recognizable. ${ }^{40}$ Candi Selokelir was originally decorated with narrative reliefs. Duijker (2010:173, figs. $61,167)$ describes a relief which was photographed by Claire Holt in 1933, depicting a scene featuring Bhima. During my visits of the site in 2000 and 2011, I could still detect a few fragments of narrative reliefs, without however being able to identify any. From some remains, such as parts of depicted legs, I could recognize the typical style of depictions of 'post-mythologial stories'. ${ }^{41}$

Stutterheim (1936b) reports the discovery of two parts of a sculpture. Initially, the body was found and thought to be the part of a female image, due to the soft forms of the body. Sometime later the head was discovered, and Stutterheim recognized the completed statue as being similar to the image of the Grogol statue. ${ }^{42}$ The characteristic element for identifying the Selokelir statue as Panji was the cap. Stutterheim (1936b:335) dates the figure to the middle of the fifteenth century, refer-

\footnotetext{
39 Watu (Indonesian) or selo (Javanese) means 'stone'. Kelir (screen) refers to the screen in the wayang performance. Thus Watukelir/Selokelir can be translated as 'screen of stone'. The name refers to the stone basement, carved with some reliefs, which was compared to a wayang screen.

$4^{\circ} \quad$ During my visit to Candi Selokelir in the year 2000 only a few parts of the terraced construction of the main site were extant. In 2011 I was happy to see the well-reconstructed site. No remains seem to be left of the other five monuments mentioned by Krom.

$4^{1}$ Same as in other remote sites, a large number of relief fragments have vanished in the course of the last years. Many stones have just been heaped up, ignoring any of the discernible connections between some relief fragments. Several fragments of narrative reliefs originating from the site are kept in the Museum Majapahit in Trowulan; they display the style reminiscent of that of Panji reliefs.

$4^{2} \quad$ See Chapter III, sub-chapter 'Kadeyan'
} 
ring to some dated stones from the Selokelir site (AD 1434) ${ }^{43}$ and to the Grogol statue of AD 1413.

The Panji sculpture is now kept in Bandung in the arts library of the University ITB (Institut Teknologi Bandung). The statue, 150 centimetres high, depicts a body, standing on a lotus cushion, with a long kain, bare chest, and the left arm hanging straight; the right arm, partly broken, holds a lotus bud in front of the body beneath the chest. The figure is adorned with jewellery - bracelets, necklace, long earrings, footrings - and with an upawita. The head is slightly bent down and gives the impression of being in a concentrated meditation. The whole body and the face have a soft, rounded shape. The neck has three wrinkles, similar to those of the Panji figure in the reliefs at Candi Mirigambar. The armpits show hair.

The hair on the head consists of some thick curls and is covered by a cap with a sharp edge. As this figure is three-dimensional, we have the rare opportunity to see the whole cap (fig. $10.13 \mathrm{c} / \mathrm{d}$ ). ${ }^{44}$ On the front and the back the cap is pointed. Between the hair and the edge of the cap a small kind of ribbon is placed. Seen from the side, the cap displays the typical crescent-moon-like shape of caps in depictions of young noblemen in two-dimensional reliefs. ${ }^{45}$

The described features identify the image as a noble person. The lotus cushion and the upawita are indications of the possible rank of a deity. The Grogol statue, in comparison, lacks the lotus cushion, the upawita, and the rich adornments, such as bracelets, a necklace, and footrings. Both figures, though the Selokelir statue to an even larger degree, display soft forms of the body and the face which are appropriate for the refined character of Panji. Stutterheim (1936b:334) claims this soft style is typical of the art of Majapahit in the fifteenth century. This in fact becomes evident in a comparison with other examples from the fifteenth century, such as the reliefs from Candi Mirigambar and from Candi Kendalisodo, with reliefs of the fourteenth century such as those on the Pendopo Terrace at Candi Panataran, which display a stiffer style.

We do not know the exact original placement of the image. Was it standing on top of one of the sanctuaries? Was it accompanied by other

43 Some inscriptions are mentioned in O.V. 1915:4.

44 The Grogol statue, which would have provided another opportunity to view the cap from all sides, is no longer extant. OD-photos only display the profile.

45 See the panels depicting Panji wearing a cap on the Pendopo Terrace at Candi Panataran. 
statues? ${ }^{46}$ The fact that the figure is freestanding like that from Grogol has led Lunsingh Scheurleer (2000:200-1) to suggest that the statue represents a deity. She presents this idea in the context of her argument that characters such as Panji and Bhima rose to the status of deities during the Majapahit period. I suggest a slightly different variation of this interpretation, namely that Panji and Bhima were worshipped in the same way as deities, but were not regarded as proper deities. I agree that Panji's being represented in a statue shows that Panji was indeed worshipped as a high-ranking character, all the more so because the Selokelir figure is depicted standing on a lotus cushion and having the upawita, which are common elements in the depiction of a deity.

A certain group of deity statues in the late Singasari and the Majapahit period have been investigated by Klokke (1994, 1998). These statues had formerly been considered as portrait statues of historical kings and queens. They display typical features of deity statues: four arms, standing on a lotus cushion, and having an upawita. Klokke comes to the conclusion that they should more appropriately be called deification images. She argues these male statues do not have individual facial features, given that most of them have a female counterpart with the same facial features. Thus they cannot portray individuals. Another aspect of the statues which must be accounted for is their hand gesture, which indicates meditation. The Old Javanese esoteric text fnanasiddhanta (Haryati Soebadio 1971) and the Nagarakertagama provide further sources for Klokke's argumentation. The Fnanasiddhanta refers to meditation as a means to acquire the ultimate truth and to unify with the Supreme God. The Nagarakertagama (Nag. 40-48; Robson 1971:52-9) mentions many deceased kings who were unified with a particular god. From all these sources Klokke concludes that the images are not individual portraits, but represent kings and queens meditating in order to become unified with the particular deity, and so become deified.

The Panji statue and these deification images possess a few common features: the stiff posture of the body, standing on a lotus cushion, with a lotus bud held in the hand, and the head slightly bent downwards. However, there are many differences as well: the Panji statue only has

$4^{6} \quad$ During my visit in 2011 I could not detect any trace in the site which would allow me to decide what the original placement of the sculpture was. The female statue from Mojokerto (inv. no. 310), exhibited in the National Museum in Jakarta, shows iconographic traits resembling the Panji statue. Further research is required to analyse whether the two statues form an original pair. 
two arms, rather than the four arms characteristic of these particular deities; Panji only holds one hand in front of the body and not both hands together in a mudra of meditation; the garment and adornment of the Panji statue is very simple; the statue is depicted wearing not a crown but a cap. The Panji figure has hair under the armpit, a feature not appropriate for a deity image, which assigns Panji a human status. Considering all these aspects of similarities and differences, I conclude that the Panji statue cannot represent a deity. However, the similarities to the deification images emphasize that indeed Panji had risen to a deitylike rank without being an actual divinity.

The Selokelir statue is an extraordinary example of the development of local East Javanese features, particularly within the context of the political and religious conditions during fifteenth-century Majapahit. Panji formed part of a local Javanese cult which had developed independently of the old Indian tradition, and he had become an object of worship. Traces of this cult were already found in the existence of the earlier Grogol statue and in the depiction of panel 9 at Candi Mirigambar where a woman sits in a sembah posture in front of the high-positioned Panji. The Panji figure of Selokelir represents the climax of this increasing rate of worship of Panji in the late Majapahit period.

Hunter (2001) argues that there was a revival of the Indian culture in Java in the fifteenth century. Heroes of the Indian epics were raised to a new, semi-divine status similar to Panji. Bhima's exorcist and purificatory qualities were intensified in myths such as the Bhimasuci, and Hanuman's bravery and his mystic qualities were, for example, exposed in the Ramayana reliefs at Panataran. They were frequently depicted in temple reliefs and in statues, and were worshipped in an even more fervent way than Panji. ${ }^{47}$ In a way, Bhima and Hanuman play a similar role as Panji, that is, as intermediaries between the wordly sphere and the Divine. However, while Bhima and Hanuman act on the level of the 'mythological stories', Panji does so within the 'post-mythological stories' - visually expressed, for example, through the different kinds of headgears. I assign a more human character to Panji than to Bhima and Hanuman, which

47 For the Bhima cult, see Stutterheim 1935a; Sbeghen 2004; Duijker 2010. For the Hanuman cult, see Klokke 2006, and Kieven 2011. The increase of the Hanuman worship in India at the same time is perhaps an indication of mutual influence between India and Java (Lutgendorf 1994, 1997). Besides Bhima and Hanuman, Lunsingh Scheurleer (2000) discusses other new objects of worship in East Java, such as Garuda. 
makes Panji even more appropriate as an intermediary. Panji does not usually act in an exorcist way, although, interestingly, Sidapaksa does when depicted as a nobleman with a cap in Candi Surowono.

A particular element of the Selokelir statue, the lotus bud, might express still another symbolic meaning. The figure holds the lotus bud in front of the lower part of the chest (fig. 13b). This part of the body corresponds to the position of the Anandakanda-padma, the seat of the ishtadewata, in the Tantric Kundalini path, which is located beneath the Anahata-cakra of the heart. ${ }^{48}$ The Anandakanda-padma is usually visually represented with eight petals (Pott 1966:34). Due to erosion we cannot decipher the number of petals of the depicted lotus flower here, so we do not know if an exact correspondence was given. However, the fact alone that the lotus was held in front of the Anandakanda-padma suggests that Panji is pointing to this very cakra, and is thus indicating the Tantric Kundalini path. This is emphasized by the meditative posture of the figure, given that meditation is an essential element in Tantric practice. Zoetmulder's findings support my argument:

We saw that the purpose of the yogi is to cause the god to be present within his body, so that he will be able to concentrate on him with all his faculties. The repeated mention of the lotus in the manggalas points in that direction, as we saw that the lotus of the heart [anandakandapadma] is the seat of the istadewata. [...] 'Although in visible form in the lotus (pangkaja), he [the god] is in the fullest sense and essentially immaterial.' [Zoetmulder quoting Hariwijaya 1.1.]

(Zoetmulder 1974:183)

$[\ldots]$ the meditation which concentrates solely upon the god in the heartlotus $[\ldots]$.

(Zoetmulder 1974:184)

Throughout the previous decades the cap had developed as a wellknown and popular feature to characterize the depiction of a nobleman and Panji in particular; Panji was clearly connected to the mundane world. Through the widespread and frequently enacted role of Panji as an intermediary between the mundane and the sacred, the Selokelir 
statue represented this intermediary position as well as a closer affiliation to the sacred sphere, owing to its deity-like attributes. This figure incorporates both spheres at the same time: the mundane and the sacred. Thus Panji is the intermediary par excellence.

I found a nice correspondence in the text by Michele Stephen (2010), in which she interprets Tantric Kundalini yoga to be inherent to the Balinese cremation ceremony. She describes this ceremony as the dissolution of the material body into ether, by which the soul is set free from earthly bonds. This dissolution is a complex process consisting of three steps: (1) the material body dissolves into the subtle body; (2) the subtle body, symbolized by the puspa-flower piercing the sixth cakra ajna between the eyebrows, dissolves into the body of bliss; (3) the 'third and final body [is then] freed from all material ties, [and] the spirit returns to its orgin, [...] pure spirit' (Stephen 2010:465). While the first two steps are described in Balinese esoteric texts, the final body is only known or admitted to be known by few Balinese ritual specialists (Stephen 2010:464), indicating its high esoteric and secret character. I see the correspondence with the role of Panji as follows: (1) Panji in his mundane character is a symbol of the material body; (2) Panji holding the lotus in front of the heart prepares for the puspa to pierce the sixth cakra, which means he prepares for the subtle body to dissolve into the body of bliss. Panji himself does not fully manifest the body of bliss, he only prepares for it. Neither does he represent the pure spirit of the third and final body, but he prepares the ground. Again he functions as an intermediary. Since the essence of Balinese rituals can be traced back to Old Javanese origins, I think that this comparison supports my understanding of the symbolism of Panji, as expressed in the Selokelir statue. ${ }^{49}$

\section{CONCLUSION}

The three sites under scrutiny display different forms of the symbolism of Panji. They all have in common that Panji acts as the intermediary

49 I propose an interpretation of Panji, one that goes beyond the interpretations I have developed so far. The Panji statue of Selokelir resembles the shape of a lingga in an anthropomorphic way, which is underlined by the cap, which looks similar to the glans. Applying the symbolism of the lingga as producing the life-giving amerta in union with the female, the Tantric principle is being signalled. This idea deserves more discussion, though it is beyond the scope of this book. 
between the mundane world and the sacred world and guides the pilgrim to proceed to an understanding of the religious doctrine.

Candi Kendalisodo demonstrates in its architectural layout and its relief depictions a concise form of the Tantric path. Panji in the Panji story prepares the pilgrim, who comes from the mundane world, for his/ her encounter with the esoteric teaching in the hermitage. The progress from the mundane to the supra-mundane stage, typical for the layout of the East Javanese temples, is here in Candi Kendalisodo displayed in horizontal form - first the pemujaan, then progressing to the pertapaan. This dichotomy corresponds, as in many other sites, to the two genres of the depicted stories: the 'post-mythological stories' - the Panji story on the pemujaan - and the 'mythological stories' - Arjunawiwaha and Bhimasuci on the pertapaan.

In Candi Yudha again Panji functions as a character who helps the worshipper to enter the sacred world and to prepare him for the Tantric path. While in Candi Kendalisodo the emphasis lay on the spiritual accomplishment, Candi Yudha's focus was more on the qualities of a kshatriya who was able to defeat the destroyer of the world order. Although no Panji story is depicted, the well-known Panji figure acts as the intermediary person who takes the visitor by the hand and points to the essential messages embedded in the relief depictions. Panji and the kadeyan are sufficient to act as indicators and intermediaries.

The communities who used the sanctuaries on Mount Penanggungan were multiple. There were hermits who stayed permanently in the sites and received pilgrims who sought advice in religious matters. These hermits had withdrawn from the world, many of them coming from an aristocratic background. Many pilgrims were members of the royal or wealthy families who might also have been the donors for the sanctuaries. Most likely, some of the sanctuaries were more exclusive than others. Kendalisodo seems to have been the ultimate and most exclusive hermitage within a large mandala of sanctuaries, and was entered only by particular seekers of Knowledge. Candi Yudha formed part of a small group of sanctuaries which functioned as places of worship and were less exclusive. The visit of this group may have prepared the pilgrim to proceed higher on the mountain to hermitages such as Candi Kendalisodo, where they received the final teaching in the religious and, particularly, the Tantric doctrine. The symbolism of the reliefs played a different role for these different categories of visitors. For the adepts willing to undergo 
teaching by the rshi, the reliefs symbolized the Tantric path, and particularly the Panji reliefs helped in the gradual approach to the final goal of this path. For a short-term pilgrim or more common people the secrets of the Tantric path were less obviously illustrated. The highest sacred doctrine was kept secret and was only to be accessed by the initiated. This seclusion on a spiritual level corresponds with the geographical seclusion and the remote location of the sites on the mountain slopes. The adept made a strong spiritual effort to achieve the Highest Wisdom; on a concrete level the adept had to make the physical effort of climbing the mountain to access the remote sites.

That the search for religious knowledge had become more important during the late Majapahit period is reflected in the large number of sanctuaries and hermitages on Mount Penanggungan. To a certain degree this was probably due to the chaotic political situation of the time, and perhaps also due to a revival of the Hindu-Buddhist beliefs against the influences of Islam. The hermitages were centres for the retreat from the world and for religious teaching.

The symbolism of Panji differed depending on the particular function of the site. In the hermitage of Candi Kendalisodo he was a guide to the religious/esoteric sphere; in the pemujaan of Candi Yudha he guided young aristocrats, showing them the way to ideal kshatriya-hood, which included the preparation for the religious teaching. In all these cases Panji depictions welcomed the visitors on their own mundane level, and the Arjunawiwaha, Bhimasuci, and Ramayana reliefs belonged to the sacred sphere which the worshippers and adepts could only enter with the help of a spiritual teacher. Panji continued in the role of intermediary, a role he had played in the temples of preceding times. Panji's symbolism as an intermediary had become well established amongst the religious community and pilgrims. Panji, being a nobleman himself, would in particular have attracted members of the aristocracy, who would have compared themselves with Panji.

The large number of Panji depictions on Mount Penanggungan reflects the increased importance and popularity of this character during the Majapahit period. This came to a climax in the transformation to a cult of worship in the final phase of Majapahit, as expressed in the Selokelir statue. The fact that the practice of this cult took place on Mount Penanggungan in particular is because of the peculiar shape of the mountain, which had been considered sacred for many centuries. 
Since sculptures were usually only erected to depict deities, in the Grogol statue and, subsequently, in the more elaborate form of the Selokelir statue Panji had risen to a very high status. The Selokelir statue with its deity-like shape may even have allowed the pilgrim and worshipper to entertain the prospect of becoming divine him/herself in the final release from worldly bonds and in the union with the Divine. Panji, in his half-human, half-divine appearance, was again the intermediary in this process. The Panji statue on Mount Penanggungan marks the climax of this whole process.

Mount Penanggungan itself is the sacred world to which the Panji statue points. The status of Panji as a guide is reinforced by the location of the statue on the foot of the mountain. Panji would welcome the pilgrims on this spot and guide them in proceeding higher up, to the sanctuaries placed on the upper slopes of the mountain, where they would receive esoteric teaching. Thus, the Selokelir statue represents the essence of the symbolism of Panji. 